\title{
Airborne fungi in Longyearbyen area (Svalbard, Norway) - case study
}

\author{
Wojciech Pusz (D) Jacek Urbaniak 무
}

Received: 27 January 2021 / Accepted: 19 April 2021 / Published online: 23 April 2021

(C) The Author(s) 2021

\begin{abstract}
Studies on the presence of atmospheric fungi in both Arctic and Antarctic polar areas are rare, and many of them were carried out briefly. Currently, when climate change is a fact, polar areas may be subject to various changes and fluctuations, negatively affecting sensitive polar ecosystems. The paper presents the results of tests on presence of fungi in the air over 30 years after the last investigations at the Svalbard Archipelago. A total of fifteen taxa of fungi were isolated in area of Longyearbyen, the majority of which were saprotrophic fungi of the genus Cladosporium that are associated with dead organic matter. Therefore, the presence of this taxon may be a good bioindicator of changes occurring in the Arctic environment, indirectly indicating the melting of glaciers and exposing increasingly larger areas inhabited by microorganisms, including fungi, which increase in number in the air. Additionally, the number of tourists visiting Longyearbyen is increasing, which may significantly affect the number and type of fungi in the air.
\end{abstract}

W. Pusz $(\square)$

Department of Plant Protection, Division of Plant

Pathology and Mycology, Wroclaw University

of Environmental and Life Sciences, Grunwaldzki Sq. 24a,

50-363 Wroclaw, Poland

e-mail: wojciech.pusz@upwr.edu.pl

J. Urbaniak

Department of Botany and Plant Ecology, Wroclaw

University of Environmental and Life Sciences,

Grunwaldzki Sq. 24a, 50-363 Wroclaw, Poland
Keywords Airborne fungi - Svalbard · Arctic · Aeromycology $\cdot$ Mycology

\section{Introduction}

Fungi, a major element of atmospheric bioaerosols, are capable of existing and surviving in the air for extended periods of time (Dowd and Maier, 1999). Both the spores and the mycelium may be dangerous for people suffering from allergies, causing various health issues including asthma (Kurup et al., 2002; Asan et al., 2004). Therefore, one of the main goals of this aeromycological study monitoring fungi present in the air was to determine the quantity of fungi posing a threat to human and animal health (Asan et al., 2004; Bugajny et al., 2005; Klarič and Pepeljnjak, 2006; Topbas et al., 2006; Palmas and Cosentino, 2009; Ianovici et al., 2011; Pusz et al., 2015). Apart from its negative impact on human health, atmospheric fungi may be dangerous for plants as sources of infection (Pusz et al., 2013; Jędryczka, 2014). Moreover, fungal organisms may be capable of creating additional toxins that are harmful to humans and animals, such as endotoxins or mycotoxins (Raisi et al., 2012).

Considering this aspect, aeromycological research is considered to be very important and predicting the future symptoms of plant diseases in both crops and wild plants (Pusz et al., 2013; Jędryczka, 2014). Such research may therefore form the foundation for creating models of pathogenic spore outbreaks in plants and 
for studying the movement of spores and other fungal organisms across larger regions (Tomassetti et al., 2011; Leyronas and Nicot, 2012; Pusz et al., 2017). Fungi capable of travelling extensive distances with wind despite natural barriers, such as tall mountains, may be particularly relevant to understanding the role of fungi in plant disease (Nagarajan and Saharan, 2007; Vaish et al., 2011; Pusz et al., 2013; Pusz et al., 2017). Notably, the presence of numerous fungal organisms pathogenic to plants has been determined in mountainous regions.

Klarič and Pepeljnjak (2006) found spores of the genera Cladosporium, Alternaria, Fusarium, Sclerotinia, or Botrytis in mountainous air at 800-900 MASL in the Zagreb area. These results have been confirmed by others (Pepeljnjak and Šegvič, 2003; Magyar et al., 2012; Pusz et al., 2017). However, aeromycological studies in mountainous regions constitute a small percentage of all aeromycological research (Xia et al., 2012; Pusz et al., 2013; Pusz et al., 2017). Even fewer such studies have been conducted in polar regions where it is critical to understand the effect of climate changes taking place in these sensitive ecosystems on fungal organisms (Wookey, 2007). To date, the few studies of this kind in the Svalbard Archipelago were conducted nearly 30 years ago and were not strictly aeromycological, focusing on different aspects. Johansen and Hafsten (1988) examined the species composition of pollen in NY-Alesund and found unidentified fungal spores. The authors only identified fungal spores of the Cladosporium genus, which constituted less than $2 \%$ of the recorded spores.

The results were confirmed during the next air sampling cycle conducted by Johansen (1991) on Jan Mayen island. This study identified Cladosporium spores again, along with Alternaria, but over $80 \%$ of spores were unidentified. These results indicate a significant lack of knowledge about the presence of fungal spores in polar regions. While aeromycological studies have been conducted in the Antarctica, only Cladosporium and Epicoccum genera were identified in the study, which constituted a small percentage of the spores (Marshall, 1997). Aeromycological studies conducted in the Arctic Ocean by Russian researchers found thirty-nine fungal taxa occurring in the air, with the highest share being the Cladosporium genus. In this study, the $\mathrm{CFU} / \mathrm{m}^{3}$ (colony-forming unit) was dependent on the distance from the sea; the value of colonies was smaller than $1 \mathrm{CFU} / \mathrm{m}^{3}$ on the isles and increased with the distance relative to human activity, such as in research stations (Kirtsideli et al., 2011). These results were confirmed in later studies, suggesting that under certain conditions, atmospheric fungi may cause negative health effects in humans inhabiting unfavourable areas, such as polar regions (Kirtsideli et al., 2017).

The goal of this study was to determine the species composition of airborne fungal spores in the Longyeardalen valley of the Svalbard Archipelago in May during the first thaw.

\section{Material and methods}

\section{Study area}

This study was carried out in the Longyearbyen area within the Svalbard archipelago, which is the northernmost $\left(78^{\circ} 130 \mathrm{~N}, 15^{\circ} 33 \mathrm{OE}\right)$ permanently inhabited city in the world. As of 2019, Longyearbyen had a population of 2.150 people. Longyearbyen has recently become a destination not only for explorers but also for leisure tourists.

According to Visit Svalbard (2021), the archipelago received 72.544 tourists in $2018-76 \%$ more when compared to the 41.037 tourists in 2008.

Longyearbyen is located at the mouth of the Longyeardalen valley in the central part of Spitsbergen Archipelago (Szymański et al., 2019). Samples were collected at five locations in $10-\mathrm{km}$-long transect, beginning at the sea coastline, to the end of the Valley Longyearbreen Glacier. The northeast facing Longyear Glacier has an area of $\sim 2.5 \mathrm{~km}^{2}$ and extends from $\sim 250 \mathrm{~m}$ to over $1000 \mathrm{~m}$ above sea level, with a mean width of approximately $500 \mathrm{~m}$ (Zawierucha et al., 2019). Samples from the air were collected twice a day (8.00 a.m.-10.00 a.m. and 18.00 p.m. -20.00 p.m.) in between 14 and 24 May 2019, in two sites on Longyearbreen Glacier: in the centre of valley and at Longyearbyen centre (Fig. 1, Table 1).

\section{Sampling collection}

Research was performed using an impact method and Air Ideal 3P device. By drawing an air sample, the device collects airborne fungal spores, which are then transferred into a petri dish and fed 
Fig. 1 Dendrogram based on the ITS sequence of the fungi obtained from the roots of the Swiss stone pine. The evolutionary history was inferred using the Maximum likelihood algorithm in MEGA7 software. The percentage of replicate trees in which the associated taxa clustered together in the bootstrap test (1000 replicates) is shown next to the branches

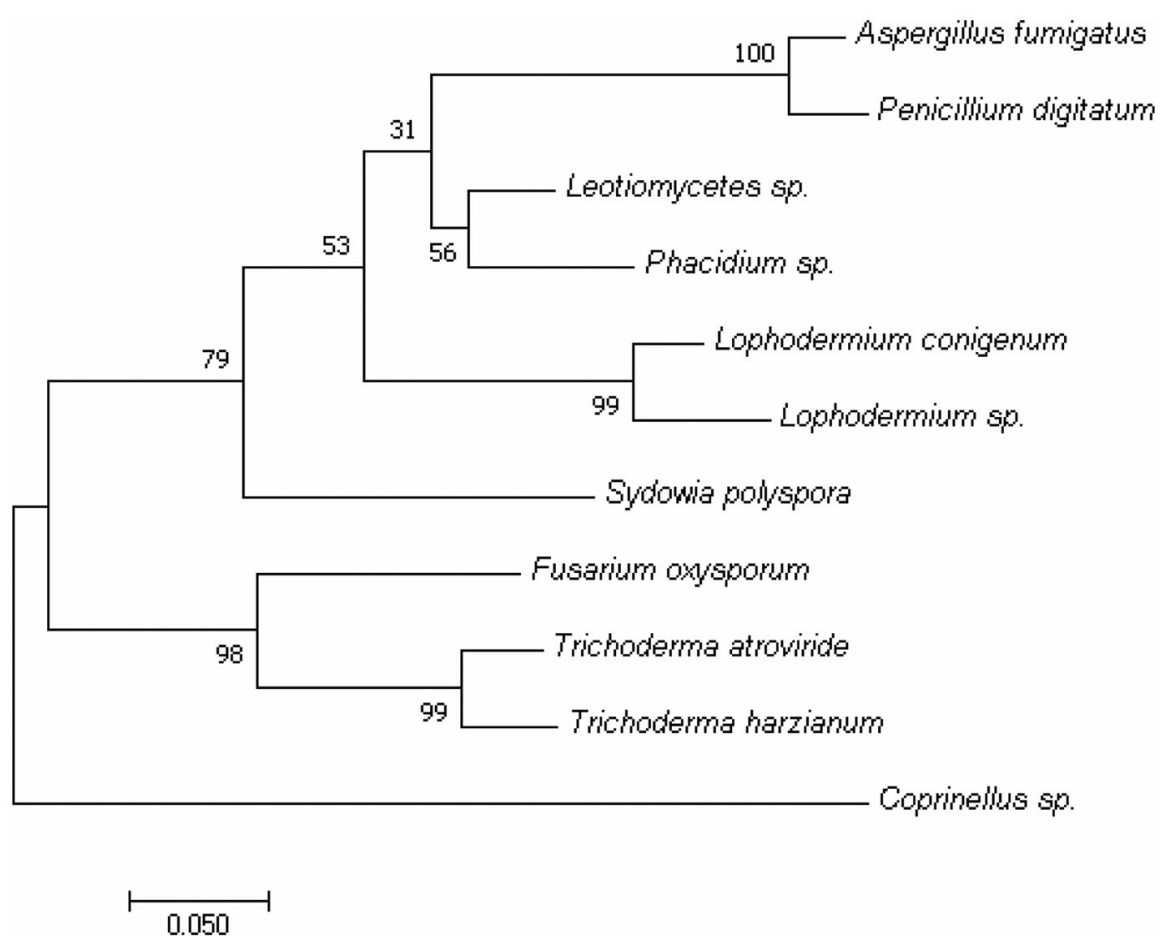

on PDA (Potato Dextrose, Agar, Biocorp) growth medium with citric acid. The device was placed $1.5 \mathrm{~m}$ above the ground and set to collect 100- and 150-L-volume samples. Measurements were taken in triplicate, and each sample was deposited on nine petri dishes. These were stored at room temperature $\left(20-22{ }^{\circ} \mathrm{C}\right)$ over a 7 to 10 day period. The next step was to identify the species of the fungi, which was accomplished by evaluating morphological features defined by Pitt and Hocking (2009) and Watanabe (2011) and then determining the number of colonies. The number of colonies grown on each dish was calculated for $1 \mathrm{~m}^{3}$ of air according to the formula:

$X=(a \times 1000) / \mathrm{V}$

where $X$ is the number of colony-forming units (CFU) in $1 \mathrm{~m}^{3}$ of air, $a$ is the total number of fungal colonies which developed on the petri dish from airborne spores, and $V$ is the volume of atmospheric air drawn, expressed in litres.

Table 1 Sampling points

\begin{tabular}{lll}
\hline $\begin{array}{l}\text { Number of } \\
\text { point }\end{array}$ & Name of sampling point & Coordinates GPS \\
\hline 1 & Top of Longyearbreen & $78.16578 \mathrm{~N}$ \\
& & $15.45300 \mathrm{E}$ \\
2 & Middle part of Longyearbreen & $78.17437 \mathrm{~N}$ \\
& & $15.47785 \mathrm{E}$ \\
3 & End of Longyearbyen (neighbourhood of 102 'Gjuestehusest') & $78.19698 \mathrm{~N}$ \\
4 & Middle of Longyeardalen (bridge near 'Huset') & $15.55847 \mathrm{E}$ \\
& & $78.20856 \mathrm{~N}$ \\
5 & Down of Longyeardalen (neighbourhood of UNIS) & $15.60030 \mathrm{E}$ \\
& & $78.22419 \mathrm{~N}$ \\
& & $15.65266 \mathrm{E}$ \\
\hline
\end{tabular}




\section{Laboratory analysis (PCR)}

In this study, molecular techniques were used for species determination. Fungal DNA was extracted with a commonly used method of nucleic acid extraction using CTAB (Doyle and Doyle, 1987). For the ITS rDNA regions, primer pairs ITS1F and ITS4 were used for species determination (White et al., 1990). The detailed PCR procedure reaction and temperature parameters were the same as those described by Pusz and Urbaniak (2017). Sequencing, post-reaction purification, and reading were performed by a nucleic acids sequencing service (Genomed S.A., Warsaw, Poland) using an ABI377XL Automated DNA Sequencer (Applied Biosystems, Carlsbad, CA, USA). Sequences were analysed with FinchTV (Patterson et al., 2004-2006) and MEGA 5.0 (Tamura et al., 2011).
Species determination was verified using BLAST software (Madden, 2002), and results are presented in Table 2.

\section{Results}

During the aeromycological analyses, the highest $\mathrm{CFU} / \mathrm{m}^{3}$ values were found in sampling location number four, in the 'Huset' region in the middle of the Longyeardalen valley. During the whole period of sample collection, nearly $4000 \mathrm{CFU} / \mathrm{m}^{3}$ was obtained, which constituted almost $90 \%$ of total CFU/ $\mathrm{m}^{3}$ (Table 3). Behind the Longyearbyen settlement in the front of the Longyearbyen glacier, the CFU value was 370 (location number three). In the middle of the Longyearbyen glacier (location number two), the

Table 2 Fungi species identified in air of Longyearbearn area in May 2019

\begin{tabular}{|c|c|c|c|c|c|c|}
\hline Species & Isolate code & Accession number & $\begin{array}{l}\text { Amplification } \\
\text { product size } \\
\text { (bp) }\end{array}$ & Query cover & Identities $(\%)$ & $\begin{array}{l}\text { Identity with } \\
\text { sequence from } \\
\text { NCBI }\end{array}$ \\
\hline Cladosporium cladosporioides & $\begin{array}{l}18 \\
28\end{array}$ & $\begin{array}{l}\text { KX6777543 } \\
\text { KX6777544 }\end{array}$ & $\begin{array}{l}561 \\
560\end{array}$ & $\begin{array}{l}99 \\
99\end{array}$ & $\begin{array}{l}99.7 \\
99.9\end{array}$ & $\begin{array}{l}\text { КС692219.1 } \\
\text { КС692219.1 }\end{array}$ \\
\hline Cladosporium floccosum & $\begin{array}{l}4 \\
12\end{array}$ & $\begin{array}{l}\text { KX6777545 } \\
\text { KX6777546 }\end{array}$ & $\begin{array}{l}560 \\
565\end{array}$ & $\begin{array}{l}98 \\
98\end{array}$ & $\begin{array}{l}99.3 \\
99.1\end{array}$ & $\begin{array}{l}\text { MK460809.1 } \\
\text { MK460809.1 }\end{array}$ \\
\hline Cladosporium iridis & 25 & KX6777547 & 561 & 95 & 100 & KJ529007.1 \\
\hline Damon diadema & 8 & KX6777548 & 559 & 99 & 99.1 & MK629946.1 \\
\hline Didymella finnmarkica & 22 & KX6777549 & 552 & 96 & 99.5 & MK876388.1 \\
\hline Microdochium phragmitis & 27 & KX6777550 & 560 & 96 & 99.3 & NR_132916.1 \\
\hline Oidiodendron cereale & $\begin{array}{l}7 \\
7 \mathrm{a}\end{array}$ & $\begin{array}{l}\text { KX6777551 } \\
\text { KX6777552 }\end{array}$ & $\begin{array}{l}530 \\
532\end{array}$ & $\begin{array}{l}98 \\
98\end{array}$ & $\begin{array}{l}99.5 \\
99.1\end{array}$ & $\begin{array}{l}\text { MH855282.1 } \\
\text { MH855282.1 }\end{array}$ \\
\hline Oidiodendron truncatum & 15 & KX6777553 & 565 & 97 & 99.1 & FJ914713.1 \\
\hline Ophiocordyceps sinensis & 26 & KX6777554 & 600 & 97 & 99.2 & KT340697.1 \\
\hline Phaeosphaeria culmorum & $\begin{array}{l}17 \\
14 \\
20 \\
21\end{array}$ & $\begin{array}{l}\text { KX6777555 } \\
\text { KX6777556 } \\
\text { KX6777557 } \\
\text { KX6777558 }\end{array}$ & $\begin{array}{l}604 \\
606 \\
606 \\
602\end{array}$ & $\begin{array}{l}95 \\
97 \\
97 \\
98\end{array}$ & $\begin{array}{l}98.9 \\
99.2 \\
99.2 \\
99.7\end{array}$ & $\begin{array}{l}\text { JX981464.1 } \\
\text { JX981464.1 } \\
\text { JX981464.1 } \\
\text { JX981464.1 }\end{array}$ \\
\hline Phoma herbarium & $\begin{array}{l}23 \\
24\end{array}$ & $\begin{array}{l}\text { KX6777559 } \\
\text { KX6777560 }\end{array}$ & $\begin{array}{l}574 \\
752\end{array}$ & $\begin{array}{l}95 \\
72\end{array}$ & $\begin{array}{l}99.3 \\
93.5\end{array}$ & $\begin{array}{l}\text { MG586981.1 } \\
\text { MG586981.1 }\end{array}$ \\
\hline Protoventuria alpina & 1 & KX6777561 & 594 & 98 & 97.4 & EU035444.1 \\
\hline Sistotrema brinkmannii & $\begin{array}{l}2 \\
9 \\
10 \\
19 \\
19 \mathrm{a} \\
16 \mathrm{a} \\
29\end{array}$ & $\begin{array}{l}\text { KX6777562 } \\
\text { KX6777563 } \\
\text { KX6777564 } \\
\text { KX6777565 } \\
\text { KX6777566 } \\
\text { KX6777566 } \\
\text { KX6777567 }\end{array}$ & $\begin{array}{l}645 \\
647 \\
643 \\
645 \\
644 \\
644 \\
645\end{array}$ & $\begin{array}{l}97 \\
97 \\
98 \\
98 \\
95 \\
96 \\
97\end{array}$ & $\begin{array}{l}99.1 \\
99.6 \\
99.1 \\
99.2 \\
99.7 \\
99.2 \\
99.5\end{array}$ & $\begin{array}{l}\text { KF218967.1 } \\
\text { KM232461.1 } \\
\text { KM232461.1 } \\
\text { KM232461.1 } \\
\text { KM232461.1 } \\
\text { KM232461.1 } \\
\text { AF261656.1 }\end{array}$ \\
\hline Thelebolus microsporus & 3 & KX6777568 & 567 & 97 & 100 & MF043977.1 \\
\hline Vishniacozyma victoriae & 13 & KX6777569 & 530 & 96 & 97.5 & LC203739.1 \\
\hline
\end{tabular}




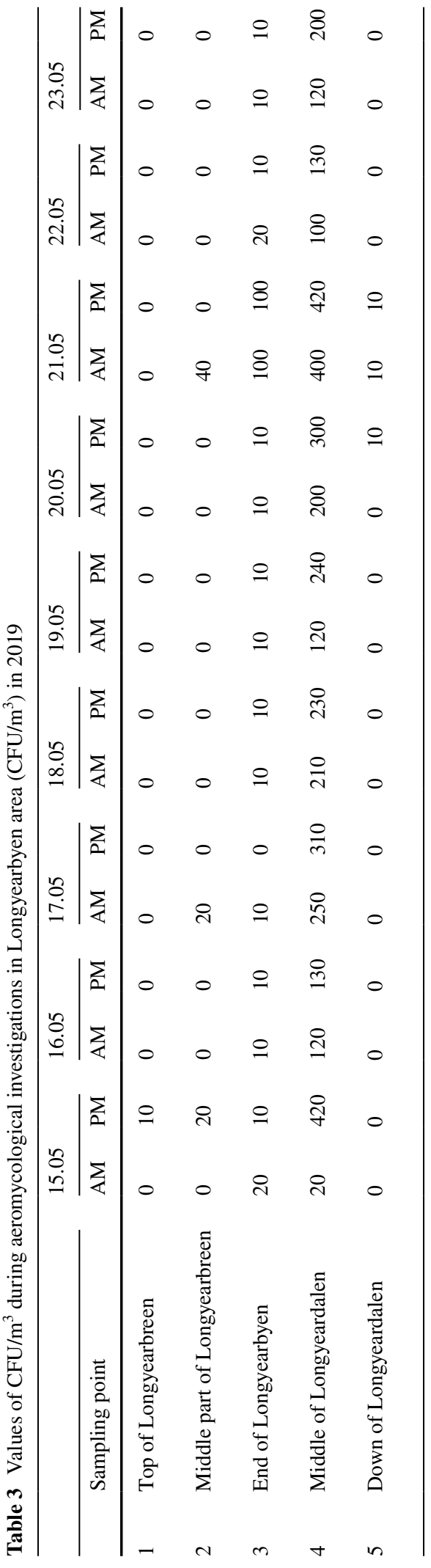

value was 80 , and at the top (location number one), the value was only $10 \mathrm{CFU} / \mathrm{m}^{3}$. On the other side of the valley near the coast, the CFU value was 30 during the whole study period. The mean value of colonies found in the air in location number four was 217 per day. Higher CFU values tended to be obtained in the afternoon sample collection. During the study, 15 fungal taxa and yeast fungi were isolated from the air in the Longyeardalen valley. Cladosporium genus, namely $C$. floccosum and C. cladosporioides, characterized the highest share of the colonies: nearly $80 \%$ of the total (Table 4). Cladosporium spores were obtained on all surfaces studied, whereas the fungi $C$. floccosum was the only species recorded at the top of the Longyearbyen glacier, in location number one. In location number four ('Huset'), $3050 \mathrm{CFU} / \mathrm{m}^{3}$ of Cladosporium genus was recorded. The same location revealed a relatively large number of the fungi Oidiodendron cereale, whose $\mathrm{CFU} / \mathrm{m}^{3}$ value reached 190. An analysis of species isolated from the air across multiple locations showed that the highest number of species occurred in locations three and four (Table 3). Moreover, also in these locations, the number of yeast fungi has reached quantity at 230 and $470 \mathrm{CFU} / \mathrm{m}^{3}$ (Table 4).

Table 4 Occurrence of fungi on air of Longyearbyen area $\left(\mathrm{CFU} / \mathrm{m}^{3}\right)$

\begin{tabular}{|c|c|c|c|c|c|}
\hline \multirow[t]{2}{*}{ Fungal taxa } & \multicolumn{5}{|c|}{ Number of sampling points } \\
\hline & 1 & 2 & 3 & 4 & 5 \\
\hline Cladosporium cladosporioides & & 10 & & 240 & \\
\hline Cladosporium floccosum & 10 & 20 & 50 & 2810 & 10 \\
\hline Cladosporium iridis & & & & 10 & \\
\hline Damon diadema & & & 10 & 20 & \\
\hline Didymella finnmarkica & & & & 10 & \\
\hline Microdochium phragmitis & & & & 40 & \\
\hline Oidiodendron cereale & & & & 190 & 10 \\
\hline Oidiodendron truncatum & & & 10 & & \\
\hline Ophiocordyceps sinensis & & & & 20 & \\
\hline Phaeosphaeria culmorum & & 10 & 10 & 40 & \\
\hline Phoma herbarum & & & & 20 & \\
\hline Protoventuria alpina & & & 10 & & \\
\hline Sistotrema brinkmanni & & 40 & 10 & 10 & \\
\hline Thelebolus microsporus & & & 20 & 40 & 10 \\
\hline Vishniacozyma victoriae & & & 20 & & \\
\hline Yeasts colonies & & & 230 & 470 & \\
\hline Total value of CFU $/ \mathrm{m}^{3}$ & 10 & 80 & 370 & 3920 & 30 \\
\hline
\end{tabular}




\section{Discussion}

[Historically, detailed aeromycological studies have a long tradition of being conducted in polar regions, though for many years, they were conducted rather superficially (Johansen and Hafsten, 1988; Johansen, 1991). Research of this kind is underappreciated and underutilized in rapidly changing polar environments (Wookey, 2007; Wojtuń and Roniker, 2018). Moreover, microorganism diversity, including diversity of fungi, may directly indicate the abundance of species in polar regions; therefore, ecological studies of microorganism groups should be conducted, including various taxonomic groups (Wutkowska et al., 2018). Aeromycological research should be a focus of future studies, since this approach can answer questions about the spreading of spores and the concentration of colony-forming fungi in regions of interest, including in extreme climates (Pusz et al., 2017).

Our findings highlight this fact, even though they significantly differ from the results of aeromycological studies conducted 30 years ago. The majority of mycoaerosol collected in the Longyearbyen area constituted of fungi of the Cladosporium genus (nearly 90\%), whereas Johansen and Hafsten (1988) recorded only $2 \%$ of Cladosporium spores in the total mass of spores obtained in the research station in NY-Alesund. A slightly higher percentage of Cladosporium genus fungi was recorded by Johansen (1991) on Jan Mayen isle, where these spores constituted nearly $5 \%$. In that particular case, the sample collection period may be significant due to the start of melting snow in arctic summer and uncovered soil surface.

Since Cladosporium fungi are saprobiontic and are weak plant pathogens (Ogórek et al., 2012) connected with organic matter and is more prevalent in polar summer in the Arctic than in thawing periods during rising temperature. These conditions occurred this year in May during the experiment. Therefore, it is possible that the higher proportion of Cladosporium fungi in the Svalbard Archipelago air may indicate changes in that environment. Glacier thawing and their regression, shorter ice cover presence, and temperature increase are factors influencing the colonization of post-glacial areas by microorganisms, including fungi (Grzesiak i Zdanowiski, 2013). This process is reflected in the current study, where the highest species abundance and the highest concentration of fungi spores were recorded in the middle of the Longyeardalen valley (location number four). During the experiment in May, snow at the location thawed rapidly revealing Arctic tundra. This is correlated with soil science research conducted earlier in Longyearbyen. The soil in the middle of the valley is characterized by a larger share of loamy and clayey fractions, as well as higher organic matter, organic carbon, and nitrogen contents (Szymański et al., 2019). Consequently, the soil is darker and heats faster, which, combined with faster thawing and high organic matter content, results in an increase in microorganism richness, including fungi. This is further indicated by the species composition of fungi, most of which are saprobiontic (Rosa et al., 2019).

Accordingly, aeromycological research could be an appropriate addition to complex ecological studies of polar regions. Fungi constitute a significant element of this environment, and their role in polar regions, including energy circulation, is not fully know yet, despite being more significant than we tend to think (Dresch et al., 2019). This study allows us to monitor the influence of fungi on the Arctic ecosystem and its inhabitants, particularly people who are living in the Arctic (Kirtsideli et al., 2017).

\section{Conclusion}

Our results indicate that the main source of airborne fungi biomass is organic material accumulated under snow. The tundra, which appears when the snow is melting, is a feeding place for animals including birds and reindeers, which also indirectly increases the concentration of fungi in the air, as well as the species richness of mycobiota. Snow yields are correlated with soil type due to organic matter content and soil colour. Compared to previous aeromycobiotic research studies conducted at Svalbard nearly 30 years ago, it is clear that there are changes taking place in the polar environment. Research studies conducted during snow melting may be compared to similar research carried out in the middle of the polar summer, taking into account the increased tourism during this period. Furthermore, the high number of tourists visiting Longyearbyen may affect the species composition and concentration of fungal spores present in the air. 
Acknowledgements The project is financed under the programme of the Minister of Science and Higher Education "Strategy of Excellence-University of Research" in 20182019 project number 0019/SDU/2018/18 in the amount of PLN 700000 .

Author contribution All authors of the paper have actively contributed to the scientific study reported in the paper and to the preparation of the manuscript.

Data Availability The datasets generated during and/or analysed during the current study are available from the corresponding author on reasonable request.

\section{Declarations}

Conflict of interest The authors declare no competing interests.

Open Access This article is licensed under a Creative Commons Attribution 4.0 International License, which permits use, sharing, adaptation, distribution and reproduction in any medium or format, as long as you give appropriate credit to the original author(s) and the source, provide a link to the Creative Commons licence, and indicate if changes were made. The images or other third party material in this article are included in the article's Creative Commons licence, unless indicated otherwise in a credit line to the material. If material is not included in the article's Creative Commons licence and your intended use is not permitted by statutory regulation or exceeds the permitted use, you will need to obtain permission directly from the copyright holder. To view a copy of this licence, visit http://creativecommons.org/licenses/by/4.0/.

\section{References}

Asan, A., Ilhan, S., Sen, B., Erkara, I. P., Filik, C., Cabuk, A., Demirei, R., Ture, M., Okten, S. S., \& Tokur, S. (2004). Airborne fungi and actinomycetes concentrations in the air of Eskisehir City (Turkey). Indoor Built Environ, 13(1), 63-74

Bugajny, A., Knopkiewicz, M., Piotraszewska-Pająk, A., Sekulska-Stryjakowska, M., Stach, A., \& Filipiak, M. (2005). On the microbiological quality of the outdoor air in Poznań, Poland. Polish Journal of Environmental Studies, 14(3), 287-293

Dowd, S. C., Maier, R. M. (1999) Aeromicrobiology. In: Maier RM, Pepper IL, Gerba CP, (eds) Environmental microbiology. Academic Press, San Diego, USA

Doyle, J., \& Doyle, J. (1987). A rapid DNA isolation procedure for small quantities of fresh leaf tissue. Phytocheml Bull, 19, 11-15

Dresch, P., Falbesoner, J., Ennemoser, C., Hittorf, M., Kuhnert, R., \& Peintner, U. (2019). Emerging from the ice-fungal communities are diverse and dynamic in earliest soil developmental stages of a receding glacier. Environmental Microbiology, 21(5), 1864-1880

Grzesiak, J., \& Zdanowski, M. K. (2013). Polar microbiocenoses in the age of global warming. Kosmos, 62(3), 341-349

Ianovici, N., Dumbrava-Dodoaca, M., Filimon, M. M., Sinitean, A. (2011). A comparative aeromycological study of the incidence of allergenic spores in outdoor environment. Ann Uni Oradea. Fascicula Biologie, 18(1), 88-98

Jędryczka, M. (2014). Aeromycology: studies of fungi in aeroplankton. Folia Biologica Et Oecologica, 10(1), 18-26

Johansen, S. (1991). Airborne pollen and spores on the Arctic island of Jan Mayen. Grana, 30(2), 373-379

Johansen, S., \& Hafsten, U. (1988). Airborne pollen and spore registrations at Ny-Ålesund, Svalbard, summer 1986. Polar Research, 6(1), 11-17

Kirtsideli, I. Y., Vlasov, D. Y., Krylenkov, V. A., \& Sokolov, V. T. (2011). Airborne fungi in the areas of Russian arctic stations near White, Barents and Kara Seas. Mikologija i Fitopatologija, 45(3), 228-239

Kirtsideli, I. Y., Vlasov, D. Y., Abakumov, E. V., Barantsevich, E. P., Novozhilov, Y. K., Krylenkov, V. A., \& Sokolov, V. T. (2017). Airborne fungi in arctic settlement Tiksi (Russian Arctic, coast of the Laptev Sea). Czech Polar Report, 7(2), 300-310.

Klarič, M. S., \& Pepeljnjak, S. (2006). A year-round aeromycological study in Zagreb area, Croatia. Annals of Agricultural and Environmental Medicine, 13, 55-64

Kurup, V. P., Shen, H. D., \& Vijay, H. (2002). Immunobiology of fungal allergens. International Archives of Allergy and Immunology, 129, 181-191

Leyronas, Ch., \& Nicot, P. C. (2012). Monitoring viable airborne inoculum of Botrytis cinerea in the South-East of France over 3 years: relation with climatic parameters and the origin of air masses. Aerobiologia, 29, 291-299

Madden T (2002) The BLAST Sequence Analysis Tool. [Updated 2003 Aug 13]. In: McEntyre J, Ostell J (ed) The NCBI Handbook. Bethesda (MD): National Center for Biotechnology Information http://www.ncbi.nlm.nih. gov/books/NBK21097/. Acessed 15 September 2019.

Magyar, D., Szöke, C., Koncz, Z., Szécsi, A., \& Bobvos, J. (2012). Identification of airborne propagules of the Gibberella fujikuroi species complex during maize production. Aerobiologia, 28, 263-271

Marshall, W. A. (1997). Seasonality in Antarctic airborne fungal spores. Applied and Environment Microbiology, 63(6), 2240-2245

Nagarajan, S., \& Saharan, M. S. (2007). Epidemiology of Puccinia triticina in Gangetic Plain and planned containment of crop losses. Wheat Production in Stressed Environments, Dev Plant Breed, 12, 71-76

Ogórek, R., Lejman, A., Pusz, W., Miłuch, A., \& Miodyńska, P. (2012). Characteristics and taxonomy of Cladosporium fungi. Mikologia lekarska, 19(2), 80-85

Palmas, F., \& Cosentino, S. (2009). Comparison between fungal airspore concentration at two different sites in the South of Sardinia. Grana, 29(1), 87-95

Patterson J, Chamberlain B, Thayer D (2004-2006) Finch TV Version 1.4.0 https://digitalworldbiology.com/FinchTV 
Pepeljnjak, S., \& Šegvič, M. (2003). Occurence of fungi in air and on plants in vegetation of different climatic regions in Croatia. Aerobiologia, 19, 11-19

Pitt, J. I., \& Hocking, A. D. (2009). Fungi and food spoilage. Springer.

Pusz, W., Kita, W., Dancewicz, A., \& Weber, R. (2013). Airborne fungal spores of subalpine zone of the Karkonosze and Izerskie Mountains (Poland). Journal of Mountain Science, 10(6), 940-952

Pusz, W., Pląskowska, E., Weber, R., \& Kita, W. (2015). Assessment of the abundance of airborne fungi in cattle barn of dairy farm. Polish Journal of Environmental Studies, 24(1), 241-248

Pusz, W., \& Urbaniak, J. (2017). Foliar diseases of willows (Salix spp.) in selected locations of the Karkonosze Mts (the Giant Mts). European Journal of Plant Pathology, 148, 45-51. https://doi.org/10.1007/s10658-016-1067-7

Pusz, W., Weber, R., Dancewicz, A., \& Kita, W. (2017). Analysis of selected fungi variation and its dependence on season and mountain range in southern Poland-Key factors in drawing up trial guidelines for aeromycological monitoring. Environ Monit and Assess, 189, 526

Raisi, L., Aleksandropoulu, V., Lazaridis, M., \& Katsivela, E. (2012). Size distribution of viable, cultivable, airborne microbes and their relationship to particulate matter concentration and meteorological conditions in a Mediterranean site. Aerobiologia, 29, 233-238

Rosa, L. H., Zani, C. L., Cantrell, C. L., Duke, S. O., Van Dijck, P., Desideri, A., \& Rosa, C. A. (2019). Fungi in Antarctica: Diversity, ecology, effects of climate change, and bioprospection for bioactive compounds. In Fungi of Antarctica.

Szymański, W., Siwek, J., Skiba, M., Wojtuń, B., SameckaCymerman, A., Pech, P., \& Smyrak-Sikora, A. (2019). Properties and mineralogy of topsoil in the town of Longyearbyen (Spitsbergen, Norway). Polar Record, 55(2), 102-114

Tamura, K., Peterson, D., Peterson, N., Stecher, G., Nei, M., \& Kumar, S. (2011). MEGA 5: Molecular evolutionary genetics analysis using maximum likelihood, evolutionary distance and maximum parsimony methods. Molecular Biology and Evolution, 28, 2731-2739. https://doi.org/10. 1093/molbev/msr121

Tomassetti, B., Lombardi, A., Cerasani, E., Di Sabatino, A., Pace, L., Ammazzalorso, D., \& Verdecchia, M. (2011).
Mapping of Alternaria and Pleospora concentrations in Central Italy using meteorological forecast and neural network estimator. Aerobiologia, 29, 55-70

Topbas, M., Tosun, I., Can, G., Kaklikkaya, N., \& Aydin, F. (2006). Identification and seasonal distribution of airborne fungi in urban outdoor air in an Eastern Black Sea Turkish Town. Turk J Med Sci, 36, 31-36

Vaish, S. S., Ahmed, S. B., \& Prakash, K. (2011). First documentation on status of barley diseases from the high altitude cold arid Trans-Himalayan Ladakh region of India. Crop Protection, 30, 1129-1137

Visit Svalbard. Statistics from Visit Svalbard. Available online: https://en.visitsvalbard.com/dbimgs/StatistikkfraVisitSv albardASper2018forweb.pdf (accessed on 11 April 2021).

Watanabe, T. (2011). Pictorial atlas of soil and seed fungi: Morphologies of cultured fungi and key to species. CRC Press.

White, T., Bruns, T., Lee, S., \& Taylor, J. (1990). Amplification and direct sequencing of fungal ribosomal RNA genes for phylogenetics. Innis $M$, Gelfand $D$, Shinsky $J$, White $T$ PCR protocols: A guide to methods and applications. (pp. 315-322). Academic Press.

Wojtuń, B., \& Ronikier, M. (2018). Polar terrestrial ecosystems: Ecology, diversity, and biogeography. Acta Societatis Botanicorum Poloniae, 87(4), 3610

Wookey, P. A. (2007). Climate change and biodiversity in the Arctic - Nordic perspectives. Polar Research, 26(2), 96-103

Wutkowska, M., Vader, A., Mundra, S., Cooper, E. J., \& Eidesen, P. B. (2018). Dead or alive; or does it really matter? Level of congruency between trophic modes in total and active fungal communities in High Arctic soil. Frontiers in Microbiology, 9, 3243

Xia, Y., Conen, F., \& Alewell, C. (2012). Total bacterial number concentration in free tropospheric air above the Alps. Aerobiologia, 29, 153-159

Zawierucha, K., Buda, J., \& Nawrot, A. (2019). Extreme weather event results in the removal of invertebrates from cryoconite holes on an Arctic valley glacier (Longyearbreen, Svalbard). Ecological Research, 34(3), 370-379

Publisher's Note Springer Nature remains neutral with regard to jurisdictional claims in published maps and institutional affiliations. 